\title{
European Research Development
}

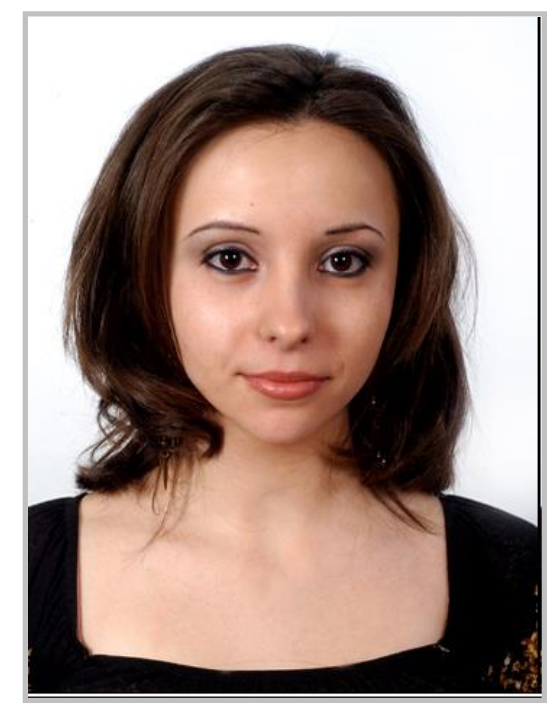

West University of Timisoara,

Faculty of Economics and Business Administration

E-mail: oana.bogdan@e-uvt.ro

"[...] Research, innovation and education are also key drivers for Europe's sustainable and inclusive recovery, boosting the resilience of our production sectors, the competitiveness of our economies and the transformation of our socio-economic systems. It goes without saying that in times of looming economic and social activity, strong investments in research, innovation and education remain indispensable. Within the EU's long-term budget, the new framework programme for research and innovation, Horizon Europe, is called upon to play a very strong role in support of the EU's competitive sustainability. The time has come to boldly turn Europe's frontier research and cuttingedge technology into solutions addressing societal challenges. Working together will make us worldwide innovation leaders and frontrunners in sustainability." [Mariya Gabriel, European Commissioner for Innovation, Research, Culture, Education and Youth]

At European Union level, "research and innovation are needed to support sustainable, inclusive and inclusive business growth, regions and countries, and to ensure that efforts to strengthen innovation systems, especially in less 


\section{ERDH 2020 - Lumen Media Publishing}

developed regions" [EU, Science, Research and Innovation performance of the EU 2020. Report May 2020, Luxembourg: Publications Office of the European Union, 2020]. Currently, the researchdevelopment activity is closely related to the activity of Sustainable Development Goals - SDGs (Figure 1).

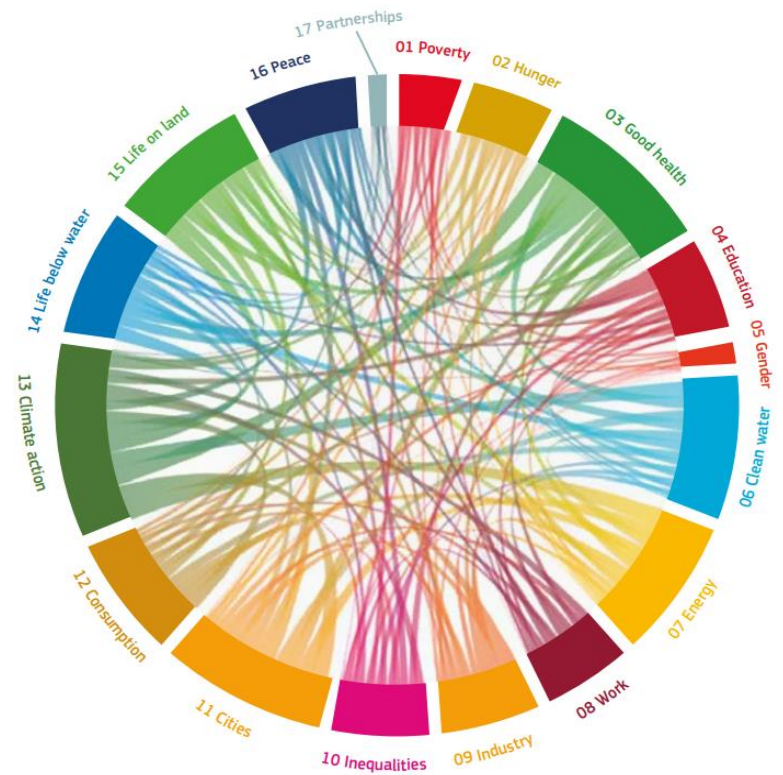

Figure 1. Overview of the interlinks between SDGs based on Horizon 2020 projects (EC, 2020, Monitoring Flash: SDGs)

Successful approaches from the perspective of economics can be found in European Research Development in Horizon 2020, Eds. Elena Hlaciuc \& Ionel Bostan, Lumen Media Publishing (London), 2013, pages: 644. According to the editors of the paper, "Given the contributions of the authors, we dare to hope that we are now closer to finding answers to the problems related to the general framework of research programs available at European level, the identification and promotion of a flexible interdisciplinary and multidisciplinary framework that best addresses the latest trends in science, society and the economy

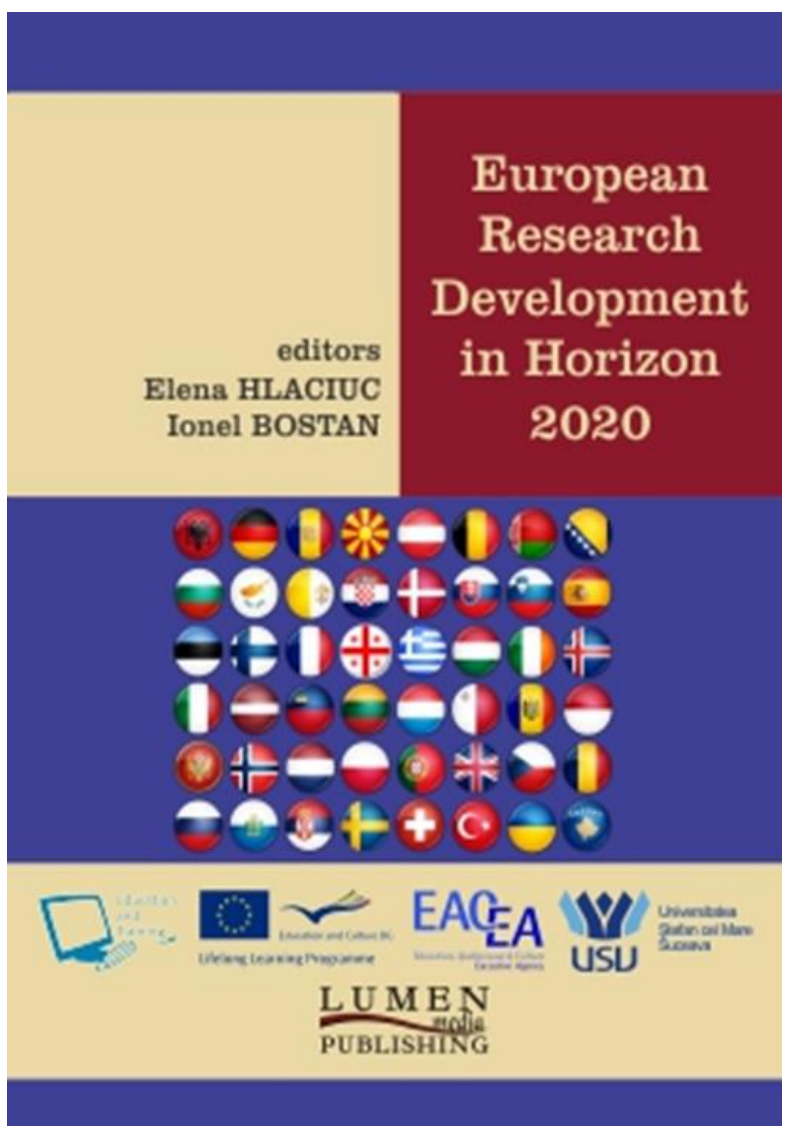

Notes of editors: "Volume appeared on the project European Development Research in Horizon 2020 within the Jean Monet Life Long Learning Programme - Key Activity 1."

or the coherence and compatibility between Horizon 2020 and policies oriented towards social cohesion that would promote research excellence."

The two editors included here two works signed in co-authorship. In fact, they are known for a whole series of articles published in specialized journals or in 


\section{ERDH 2020 - Lumen Media Publishing}

scientific volumes [1-63]. The works in question are: Optimization the role of financial and internal audit in accounting fraud prevention (V. Grosu, E. Hlaciuc, I. Bostan et al.; Doctoral research in Romania - an opportunity for creativity and originality (M. Moraru, I. Bostan, E. Hlaciuc, V. Grosu). Other topics covered in the same volume by various authors are: A

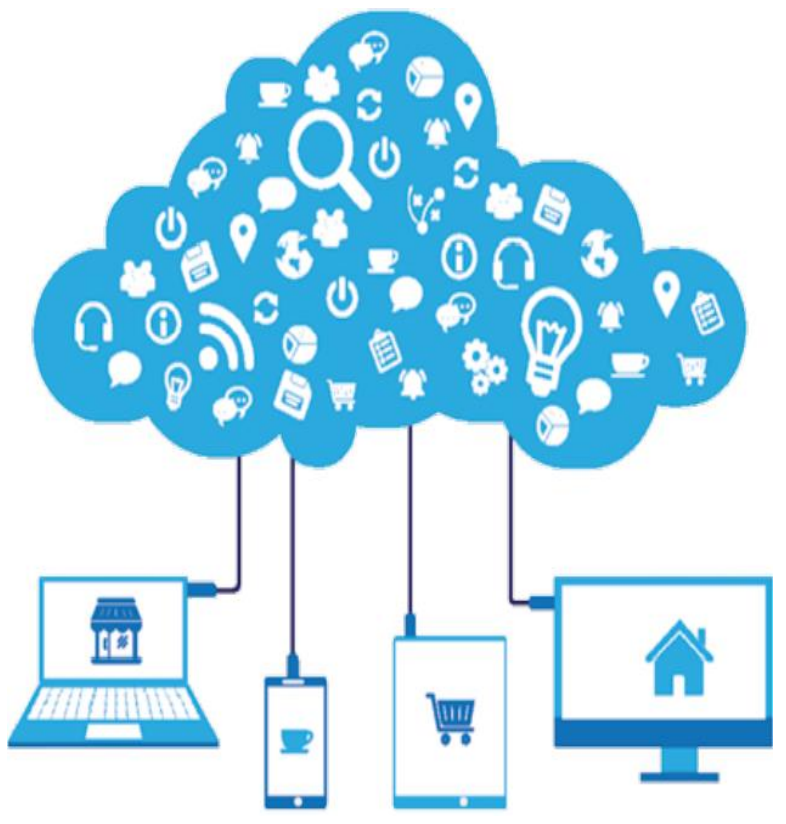

post-modern criticism of the modern managerial ethics (B. Andronic, V. Dumitrașcu); Impact of tourism on the environment - typologies (G. Arionesei, D. Neamțu, A. Lelcu); Comparative analysis of real convergence among member of CSEE (A.N. Apetri, A.M. Hlaciuc; Demographic decline - the main challenge of the Romanian future economy ( $R$. Barrbulescu); Lifelong learning - essential concept and attitude for education (D. Botez); The research and development, seen as strength determinative of the ecnomic growth (G.L. Cioban); Optimization of economic and financial communication of SMES by implementing the IFRS (M.S. Ciubotariu, I.C. Colbu; The components of deposit policy of banks and contemporary requirements imposed by Eurosystem (L. Cobzari, N. Băncila, A. Margineanu); Financial communication of SMES during economic crises: can the international financial reporting standards make a difference? (I.C. Colbu, M.S. Ciubotariu); Audit expectation gap: fundamental questions and possible solutions (G.S. Cordoș, M. Timea Fuilöp); International opinions about reporting of the public sector service performance information (A.I. Coste); EPSAS - a real need or just a European fashion? (A.R. Crișan); The financing of R\&D: challenges for Romanian firms (M. Diaconu); Competitiveness of the information and communication technologies of the Republic of Moldova (L. Dodu-Gugea); Identifying the old boundaries and new challenges in the development of scientific research (A. Domil, A. Artene, S. Artene, D. Mateș); Tax policy in EU member states after the 2008 crisis (A. Dornean, B. Firtescu); Mission and vision fundamental reference points within business organization (M.C. Eși, N.L. Posteauca); The impact of new information and communication technologies in the creation and dissemination of knowledge (M. Georgescu, D. Popescul, I. Georgescu); Sustainability in fiscal policy in boom and recession - the case of Romania (M. Göndör); SMEs and CSR in emergining 


\section{ERDH 2020 - Lumen Media Publishing}

economies of European Union (M. Grosu, C. Mihalciuc); Euro - a powerful engine of economic-financial integration (A.M. Hlaciuc, A.N. Apetri); Abuse of rights in trade agreements from the perspective of E.U. regulation (C. Ignatescu); Selective issues concerning the education and financing the education in Romania ( $R$. Kicsi, S. Buta); Some aspects of performance measurement at the level of a non-refundable foreign-funded project (M. Man, M. Macriș); The dynamic role of R\&D, exports and GDP on the explanation of electricity consumption: evidence from a SW EU country (J.R.P. Manso, A.M.C. Marques, J.A.S.R. Fuinhas, N.B. Behmiri, A.R. Nascimiento); Understanding the real significance of figures: the role of accounting, control and audit in preventing corruption, underground economy and tax evasion (A.D. Matei); Corruption and capture of the clientelar democracies, an invisible threat in the heart of the European Union (L.F. Madeira); Optimizing the impact of public funding on scientific research (D. Mateș, G. Maciuca); Stages of accounting reform in Romania and the structure of annual financial statements established by the normalizers (C. Mihalciuc, M. Grosu, A.M. Zaiceanu, L.E. Scurtu); Public vs. private sector accounting (I. Mitu, A.I. Coste); Structural analysis of suceava county's economy - transition from planned to market economy (A.A. Moroșan, C.V. Hapenciuc); The efficiency of Romanian banking system - evolution, causes, solutions (G. Moroșan); Formation of competences in economic field (L. Moroșan-Danila, O.M. Bordeianu); Market and marketing research in economy and public administration (A.M. Nedelea, M.O. Nedelea, A. Larion); Education for sustainable development - social and territorial cohesion vector (V. Platon, A. Constantinescu); The role of evaluation in

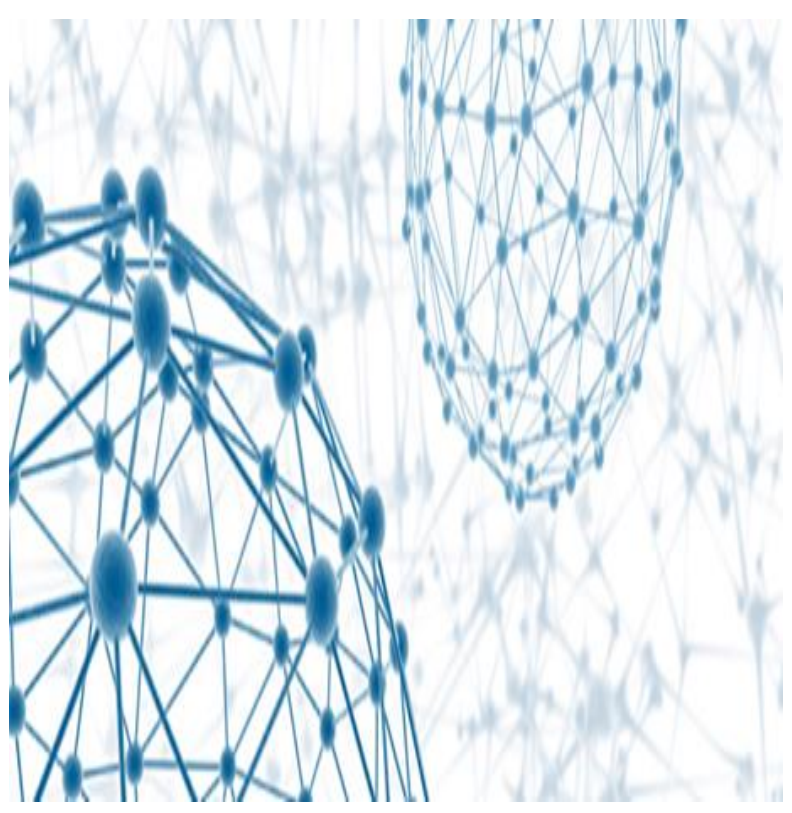

presenting the fiar view in financial statement (O. Pleșco); A glimpse of social media impact in project management (D. Popescul, M. Georgescu); Material personal responsibility in the insolvency procedure (T.A. Radulescu); Romania: the state of the nation. Post-crisis economic challenges (T.A. Radulescu, A.M. Hlaciuc); Value relevance of performance indicators in business valuation (N. Tabara; A. Vasiliu); Connection bookkeeper - auditor throughout the concept of Nash equilibrium (F.E. Tanasa, E. Horomnea, N. Tabara); European convergence sustainability (M. Vartolomei); Innovative 


\section{ERDH 2020 - Lumen Media Publishing}

interpretation of cultural heritage and local sustainable entrepreneurship development. Case study on Romania in(di)visible Bucharest (V. Vasile, I. Login). Analysis of under-appreciation and over evaluation of shares listed on the Bucharest stock exchange by using per (A. Vasiliu); A new approach to shadow economy metrics of international comparisons EU countries (G. Zaman, Z. Goschin); Economic and social analysis of economic gaps, between 1990-2012, the influence factors (R. Zorzoliu). Certainly, the approaches of the young researchers who signed the above-mentioned works facilitate the understanding of the circumscribed far-reaching concerns. The idea is that the funds allocated to research are low and that performance in this area depends on increasing the amounts from the state budget. But here is some recent data in this regard, in the European context (Eurostat, November 2020). If at EU level, research and development expenditures were in $2019=2.19 \%$ GNP (compared to 2.18 in 2018 and 1.97\% in 2009), Romania allocates less than $1 \%$ of GDP, occupying one of the last places in this ranking.

It should be noted that, in the EU-27 (2019), $2 / 3$ of the funds for research and development were directed to companies and business ideas, while academic research accounted for just over $1 / 5$.

Therefore, we believe that it would be important for the two publishers to relaunch a similar approach, which will analyze and debate the new data and information of 2020, the latest strategies issued in the field, possibly giving the necessary priority to the economic effects of the pandemic. COVID-19.

\section{Reference}

[1]. Mates, D.; Grosu, V.; Hlaciuc, E.; Bostan, I.; Bunget, O.; Domil, A.; Moraru, M.; Artene, A. (2015). Biological assets and the agricultural products in the context of the implementation of the IAS 41: A case study of the Romanian agro-food system. Arch. Biol. Sci., 67, 705-714. DOI:http://dx.doi.org/10.20961/jab.v19i2.449.

[2]. Socoliuc, M.; Grosu, V.; Hlaciuc, E.; Mateș, D.; Bostan, I.; Bunget, O.; Moraru, M. (2013). Difficulties encountered in defining and measuring intellectual capital. Technics Technologies Education Management, 8(4): 1774-1779.

[3]. Bostan, I.; Grosu, V.; Hlaciuc, E.; Mates, D.; Burciu, A., Socoliuc, M., Bunget, O., Domil, A., Moraru, M., Peres, C., Petrisor, B., Dumitrescu, A.-C., Artene, A., Andronic, B. (2013). The environmental audit (EA) and the environmental balance sheet (EBS) in Romania. J. Food Agric. Environ., Vol.11 (3\&4), 2587-2592.

[4]. Bostan, I.; Mateş, D.; Hlaciuc, E.; Grosu, V.; Iancu, E.; Socoliuc, M. (2010). Implications of the EVA model use in the firm resources' performant allocation plan. The Journal of Accounting and Management Information Systems, Vol. 9, No. 1/2010, pp. 120-145.

[5]. Bostan, I.; Hlaciuc, E.; Iancu, E.; Nemtoi, G. (2009). Reflecting the compliance and performance degree in the special reports of the European Court of Accounts, The Annals of The "Ştefan cel Mare" University Suceava, ISSN:1582-6554, Fascicle of The Faculty of Economics and Public Administration, Vol. 10, Issue (Month): 1(11), pp. 110-116, 


\section{ERDH 2020 - Lumen Media Publishing}

[6]. Asaloș, N.; Hlaciuc, E.; Bostan, I., Roman, T.; Mateș, D.; Manolică, A. (2016). Mining remittances corresponding to metalliferous ores: regulation and budget impact. Metalurgija, METABK 55(2) 278-280, UDC - UDK 622.01.23:533.3:669.2/8:339.6:65.011 =111.

[7]. Hlaciuc, E.; Bostan, I.; Grosu, V.; Socoliuc, M. (2013), Limitations and perspectives in the process of economic and financial harmonization in EU. In Vol. - 22nd International Business Information Management Asociation (IBIMA) Conference, Rome, Italy 13-14 November 2013, pp.976-985.

[8]. Socoliuc, M.; Bostan, I.; Mates, D.; Grosu, V.; Hlaciuc, E.; Mihalciuc, C.; Colbu, I. (2012). Compatibility of the romanian accounting system with the standard IAS/IFRS System. 17th International Scientific Conference SM-2012 Strategic Management and Decision Support Systems, Sesija B / Session B (S8) Subotica, Ekonomski fakultet, April 20, 2012, University of Novi Sad, http://www.ef.uns.ac.rs/sm2012/download/agenda-sm2012-v12.pdf, in Vol. STRATEGIC MANAGEMENT 17 (3), pp. 054-063, UDC:005.334:653.4.

[9]. Bostan, I. (2010). Recompensa si performanta in economia concurentiala. Editura TipoMoldova, Iasi.

[10]. Bostan, I.; Clipa, F.; Clipa, R.I. (2018). Is Romania a Sustainable Developed Country? An Analysis of Ecological Footprint (EF) in Correlation with Human Development Index (HDI). Logos Universality Mentality Education Novelty: Economics \& Administrative Journal, Volume 3, Issue 1, Pages 5-14.

[11]. Bostan, I.; Popescu, C.; Istrate, C.; Robu, I.B.; Hurjui, I. (2017). The impact of taxation of the domestic economic transactions on the VAT collection through electronic fiscal devices. Amfiteatru Economic 19 (45), 581-594.

[12]. Bostan, I. (2016). International trade of Romania in the context of its low economic potential. CES Working Papers 8 (4), 611-624.

[13]. Bostan, I.; Popescu, C.C.; Dascalu, E.D.; Firtescu, B. (2016). The European Union cohesion policy and external migration in Romania. Multistage analysis. Rev. Cerc. Interv. Soc., Vol. 54, 96-114.

[14]. Bostan, I.; Onofrei, M.; Popescu, C.C.; Lupu, D.; Firtescu, B. (2018). Efficiency and Corruption in Local Counties: Evidence from Romania. Lex Localis - Journal of Local Self-Government. Vol. 16, No. 1, pp. $215-229$.

[15]. Clipa, F.; Bostan, I.; Clipa, R. (2016). Financial audit as a manifestation of institutional entrepreneurship. Knowledge Horizons - Economics, 8 (3), 33-37.

[16]. Bostan, I.; Lazar, C.M.; Asalos, N.; Munteanu, I.; Horga, G.M. (2019). The three-dimensional impact of the absorption effects of European funds on the competitiveness of the SMEs from the Danube Delta. Industrial Crops and Products, 132, 460-467.

[17]. Anton, S.G.; Bostan, I. (2017). The Role of Access to Finance in Explaining Cross-National Variation in Entrepreneurial Activity: A Panel Data Approach. Sustainability, 9 (11), 1947.

[18]. Bostan, I. (2010). Controlul financiar al afacerilor. Bucuresti: Universul Juridic.

[19]. Bostan, I.; Condrea, P.; Burciu, A.; Morariu, A. (2009). HRM Motivational Component: Maslow and Alderfer. Contrast Perspectives. International Conference. SSRN. http://dx.doi.org/10.2139/ssrn.1340959.

[20]. Bostan, I. (2005). Managementul recompensei. Suceava: Editura Universităţii "Ştefan cel Mare".

[21]. Bostan, I. (1999). Recompensarea factorului muncă. Iaşi: Media Tech.

[22]. Bostan, I.; Mates, D.; Grosu, V.; Socoliuc, M. (2008). Implications of fiscality over accounting in agriculture. Bulletin of University of Agricultural Sciences Cluj-Napoca. Horticulture, Economics and Management Miscellaneous, 65(2):432.

[23]. Tinică, G.; Bostan, I.; Grosu, V. (2008). The dynamics of public expenses in healthcare and demographic evolution in Italy and Romania. Revista Romana de Bioetica, 6(3), 56-63.

[24]. Bostan, I. (2012). The balanced scorecard (BSC) implications on the increase of public companies performance. African Journal of Business Management, 6 (22), 6465. 


\section{ERDH 2020 - Lumen Media Publishing}

[25]. Bostan, I.; Grosu, V.; Iancu, E. (2009). The role and importance of economic and financial information in corporate governance. Annales Universitatis Apulensis: Series Oeconomica, 11 (1), 163.

[26]. Lazăr, C.M.; Hurjui, I.; Asaloş, N.; Bostan, I. (2019). Audit of Forest Restitution Process. Some Findings Regarding the Romanian Space in the Post-Communist Stage. Logos Universality Mentality Education Novelty: Law, 7(2), 66-79. https://doi.org/10.18662/lumenlaw/28

[27]. Socoliuc, O.R.; Bostan, I.; Ignat, A. (2018). Pleading for a Good Cooperation between Institutions and Organisations in the Process of Acquiring Sustainable Development. Case Study on Romanian Agricultural Cooperatives. Acta Universitatis Danubius. Relationes Internationales, 11(1).

[28]. Vodă, A.I.; Bostan, I.; Ţigănaş, C.G. (2018). Impact of macroeconomic and healthcare provision factors on patient satisfaction. Current Science (00113891), 115(1).

[29]. Bostan, I.; Firtescu, B.N.; Toderascu, C. (2018). Exchange Rate Effects on International Commercial Trade Competitiveness. J. Risk Financial Manag., 11(2), 19; doi:10.3390/jrfm11020019, https://www.mdpi.com/1911- 8074/11/2/19/htm

[30]. Voda, A.I.; Bostan, I. (2018). Public Health Care Financing and the Costs of Cancer Care: A CrossNational Analysis. Cancers, 10 (4), 117.

[31]. Popescu, C.C.; Bostan, I. (2016). Gold coinage. Case study: Romania and Republic of Moldova. Ecoforum Journal, 5 (2(9)), 236-240.

[32]. Bostan, I.; Nicula, C. (2017). Interventions on the legal framework of financial-budgetary reasons of national defense. The 19rd International conference "Scientific research and education in the Air Force Henri Coanda”, AIR FORCE ACADEMY, pp. 49-56, DOI:10.19062/2247-3173.2017.19.2.7, Braşov, May $25-27$.

[33]. Roman, T.; Lazar, C.; Manolica, A.; Bostan, I. (2016). The current trends and opportunities in the industry of medical tourism. Journal of tourism - Studies and research in tourism, 22, 58-63.

[34]. Bostan, I. (2016). Investigating the effectiveness of programs on health financing based on audit procedures. Iranian Journal of Public Health, Vol. 45, No. 8, Aug, pp. 1074-1079.

[35]. Bostan, I.; Lazar, C.M.; Hurjui, I.; Asalos, N. (2019). Analysis of the Formation and Allocation of Resources Directed at Funding Environmental Projects and Programmes (EPP). Logos Universality Mentality Education Novelty: Political Sciences and European Studies, 5(1), 46-58. doi: 10.18662/lumenpses/08

[36]. Bostan, I.; Roman, T.; Manolică, A.; Morariu, A.; Năstase, C.; Asaloș, N. (2016). Changing attitudes towards the environment by using corporate social responsibility (CSR) campaigns in the oil industry. Environ Eng Manage J, 15(6).

[37]. Bostan, I.; Dascălu, E.D. (2016). Strengthening the Sustainability of Public Finances by means of Financial Law focused on exercise Control and Audit activity. Ecoforum, Vol. 5, Issue 1(8), pp. 387-393.

[38]. Bostan, I.; Grosu, V. (2010). The Role of Internal Audit in Optimization of Corporate Governance at the Groups of Companies. Theor. Appl. Econ., 17, 63-84.

[39]. Bostan, I.; Grosu, V. (2010). Economical and managerial influences in the public health systems. Revista Română de Bioetică, 8(2):97-103.

[40]. Bostan, I.; Burciu, A.; Condrea, P. (2010). Trends of the communitarian cohesion policies and advertising for eco-investments. Environ Eng Manag J, 9(6):847-851.

[41]. Bostan, I.; Onofrei, M.; Dascălu, E.D.; Fîrțescu, B.; Toderașcu, C. (2016). Impact of sustenaible environmental expenditures policy on air pollution reduction, during European integration framework. Amfiteatru Economic, 18 (42), 286-302

[42]. Bostan, I. (2003). Controlul fiscal. Iaşi: Polirom.

[43]. Bostan, I. (2005). Guidelines in the audit of Risk assessment. Comunicare susţinută cu ocazia Conferinței, Probleme actuale ale situației ale situatiei social-economice a Republicii Moldova, 


\section{ERDH 2020 - Lumen Media Publishing}

organizată de Facultatea de Ştiințe Economice a Universităţii de Stat, Vol. 1, Pages 215, Publisher: USM Chisinau.

[44]. Bostan, I.; Burciu, A.; Condrea, P.; Durac, G. (2009). Involvement of legal responsibility for severe acts of pollution and noncompliance. Environ Eng Manage J, Vol. 8, Issue: 3, Pages: 469-473.

[45]. Bostan, I. (2016). Leveraging Sustainability as Budgetary resources through Financial Law Instruments. Annals "Constantin Brâncuşi" University, Economy Series, 33-42.

[46]. Bostan, I. (2016). Pro sustainable development: The influence of the law of entropy on economic systems. Environ Eng Manag J, 15 (11), 2429-2432.

[47]. Bostan, I. (2016). Considerations on insufficient legal regulation of special allocations made by the central executive authority. Journal of Public Administration, Finance and Law, 9 (1), 119-124.

[48]. Bostan, I. (2014). Juridical tools of Governmental nature used to mitigate various difficulties of the Financial and Budgetary System. Annals of the Alexandru Ioan Cuza University-Economics, 61 (2), 133148.

[49]. Bostan, I.; Firtescu, B.N.; Nicula, V.C. (2018). The Role of Supreme Audit Institutions in Promoting and Strengthening Ethics and Integrity in the Public Sector. Possible Models and Tools to Follow. Journal for Ethics in Social Studies, 2(1), 43-52, https://doi.org/10.18662/jess/08

[50]. Socoliuc, O.R.; Bostan, I.; Ignat, A. (2018). Pleading for a Good Cooperation between Institutions and Organisations in the Process of Acquiring Sustainable Development. Case Study on Romanian Agricultural Cooperatives. Acta Universitatis Danubius. Relationes Internationales, 11(1).

[51]. Bostan, I. (2016). An analysis of the "bio" / "eco" products market, referring to the EU and Romania. CES Working Papers, 1 (8), 33-44.

[52]. Tinică, G.; Bostan, I.; Grosu, V. (2013). Corelaţii privind creşterea economică şi evoluţia costurilor aferente maladiilor cronice. Revista Română de Bioetică, 8 (3), 15-24.

[53]. Pohoață, I.; Socoliuc, O.; Bostan, I. (2013). The Economic Impact of Religious Tourism on The North East Region of Romania. European Journal of Science and Theology2, 9 (2), 195-204.

[54]. Bostan, I.; Pohoata, I.; Lazar, C. (2013). State control over commercial transactions with goods from precious metals. Metalurgija, 52 (4), 553-556.

[55]. Bostan, I. (2010). Considerations on insufficient legal regulation of special allocations made by the central executive authority. Journal of Public Administration, Finance and Law, 9 (1), 119-124.

[56]. Bostan, I. (2016). Impactul sistemului financiar-fiscal asupra derulării schimburilor comerciale internaţionale. Iaşi: Tipo Moldova.

[57]. Bostan, I. (2010). Drept bugetar european. Iaşi: Tipo Moldova.

[58]. Bostan, I. (2008). Drept financiar. Iasi: Editura Tehnopress.

[59]. Bostan, I. (2007). Drept financiar comunitar. Iaşi: Tipo Moldova.

[60]. Bostan, I. (2000). Controlul financiar. Iaşi: Polirom.

[61]. Burciu, A.; Bostan, I.; Condrea, P.P.; Grosu, V. (2010). Financing the environmental policies in the Communitarian space. Environ Eng Manage J, 9, 1179.

[62]. Bostan, I.; Grosu, V. (2009), Limits on legislative harmonization financial accounting. The 33rd Annual Congress of the American Romanian Academy of Arts and Sciences (ARA), Politechnic International Press Montreal, Quebec, pp. 250- 253.

[63]. Condrea, P.; Bostan, I. (2008). Environmental issues from an economic perspective. Environ Eng Manage J, Vol. 7, No. 6, pp. 843-850. 